\title{
URBAN DEVELOPMENT TRENDS IN THE LATGALE REGION AT THE BEGINNING OF THE 21ST CENTURY
}

\author{
Ivars Matisovs \\ Rezekne Higher Education Institution, Faculty of Engineering \\ Atbrīvošanas aleja 76, Rezekne, Latvia \\ Ph.: +(371)26453990, fax: +(371)64625167, e-mail: ivars.matisovs@ ru.lv
}

\begin{abstract}
The paper provides a comprehensive analysis of urban development trends in the Latgale region, observed at the beginning of the 21 st century and to a large extent also outlines the direction of future development. The paper is based on the evaluation of spatial development planning documents, the analysis of the available statistical data and the review of the urban development projects subject to implementation, supplemented by some results of field studies on the urban environment quality. Though the urban environment and partly also the landscape quality has been improved during the last period, as well as in many areas with support of the EU programmes major urban environment development projects are being implemented, however the economic growth is stalling, depopulation processes are not contained, and the regional urban development index is expressly negative. In the course of the administrative and territorial reform the status of the majority of towns and cities of the Latgale region has significantly changed, and sustainable urban development in the region is still under real threat.
\end{abstract}

Key words: depopulation, Latgale region, urban development, urban environment quality.

\section{Introduction}

Urban development process is continuous in time and space and is closely related to the overall social development trends. Structural changes in the economy and increasing population mobility have modified the urban development perspectives. Urban development of the Latgale region nowadays is actually determined by the same processes that commenced in the 90-ties of the past century, along with Latvia regaining its national independence and with transition from the planned centralized economy to spontaneous development based on the free market principles. Exactly during the periods of economic boom or recession, the urban economic potential and demographic situation change significantly, considerable changes occur to the shape of urban landscape and the socio-psychological space [1].

Activities based on the new knowledge are concentrated in large agglomerations, but some remote regions, including Latgale, with less competitive urban centres are considerably lagging behind in their development. In these areas strengthening of the urban functions is required, which to a great extent would allow to restrict the population decline, since this process greatly reduces the functionality of areas and makes provision of services to citizens difficult [2].

Currently, on both the European Union and the Latvian scale there has been a significant change from the previous views to the spatial development issues and the integrated view to urban and regional development is increasingly used. The Territorial Agenda for the European Union sets a priority task of the need to facilitate polycentric development and innovations, via extensive use of urban cooperation networks [3]. Emphasis is placed also on searching for new forms of territorial governance and cooperation between urban and rural areas. The Latvian National Development Plan 2007 to 2013 is also highlighting polycentric national development, with application of the urban development potential and capacity to affect the development of wider areas, as well as to create urban networks as a precondition for sustainable national development [4].

In Latvia during 2007 a priority of "Polycentric Development" co-funded by the ERDF was developed, in order to promote urban competitiveness. It is intended for each city to highlight 
and to strengthen their specific development potential, which would complement activity profiles selected by other cities, as well as would support processes having a beneficial impact on the development of neighbouring territories [5]. Within the priority framework, provision of support to regional development centres is planned, among which in Latgale are listed Daugavpils, Rezekne and Lìvāni. In determination of beneficiaries also the urban socioeconomic development indicators are taken into account, by assessing the concentration of resources required for maximum return on investment and amount of investment, which will be available for the cities from other support activities of the EU funds from 2007 to 2013.

It should be noted that the towns and cities of the Latgale region are exactly among the first ones in the country having developed programmes appropriate for the EU criteria. For example, emphasis of the Daugavpils City Development Programme (2008-2014) is laid on cultural and ethnic diversity of the city as well as its multifunctionality, positioning the city as an important cross-border economic development and service centre [6]. While the Rèzekne City Integrated Development Programme (2007-2013) highlights importance of the city as major cultural and educational centre for the Eastern Latvia [7]. Medium-term development programmes are elaborated in Balvi, Krāslava, Lìvāni, Ludza and Preilii, and are also in the making in Dagda, Ilūkste and Kārsava. These programmes provide for integrated development of the cities and newly established regions as well.

\section{Materials and methods}

Urban development is a complex multidimensional process; hence the analysis of its trends requires an integrated approach, involving use of various types of information sources.

First, these are normative and planning documents, which determine development of areas at different scales, i.a., also urban development programmes and plans.

Second, comprehensive statistical information that defines processes and trends of the urban spatial, socio-economic and demographic development.

Third, data obtained during the urban environment quality field research, such as traffic intensity measurements and air quality assessment.

For situation analysis in urban areas of the Latgale region, information summarized by the Central Statistical Bureau of Latvia, as well as publicly available data of other public bodies and results of individual studies are mainly used. Objective assessment of the existing situation is significantly encumbered by insufficient availability of information, because in Latvia statistical data on the administrative territories at the level of local municipalities (cities, towns, civil parishes and municipalities) has not been published since 1998 [8]. Only in demographic yearbooks figures for all cities and towns in the region are found, but in other areas detailed information is available only for the cities of republican subordination Daugavpils and Rezekne, while liquidation of districts and creation of municipalities, which took place in the course of implementation of the administrative-territorial reform, has brought about problems in mutual comparability of statistical data.

For urban development evaluation in Latvian the territorial development index (TDI) is used, the methodology for calculating this was developed by the Latvian Statistical Institute in 2000. TDI and the territorial development rank are generalized or composite indicators of the territorial development level and assessment of the development trends. It is recognized that elaboration of professionally convincing development indices for cities and towns is much more difficult than for the rural areas. Experts have set out key development factors and scales for their importance, which are used to calculate some Latvian urban development indices as follows: unemployment rate (0.30), individual income tax per 1 person (0.30), demographic burden $(0.20)$ and changes in permanent population during five-year period (0.20) [9].

In this study, the following urban development indicators were mainly used: 1) demographic data, placing emphasis on the importance of population dynamics in evaluation of the 
development potential of settlements, 2) environmental ecological quality parameters as indicators by using the volume of air pollution from stationary sources and intensity of traffic flows, 3) implementation of projects relevant for improvement of the urban environment quality. Less attention this time was paid to the economic development indicators and analysis of the urban environment attraction factors.

\section{General information}

\section{Results and discussion}

The Latgale region covers the area of $14,547.2 \mathrm{~km}^{2}$ or $22.5 \%$ of the state territory and at the beginning of 2010 the population of the region was 339,783 people or $15.2 \%$ of the total Latvian population. There were 191,035 people living in urban areas and the urbanization rate in Latgale reached $56.2 \%$, while more than $40 \%$ of the regional population was concentrated in Daugavpils and Rezekne. Since 1990 the urban population of Latgale has decreased by approximately $22 \%$, while the degree of urbanization in the region has not significantly changed.

Still disputable is the question of number of cities and towns in the Latgale region. Thus, for example, the Latgale Urban Development Strategy developed in 2001 identifies 17 cities and towns in the region [10], including Jēkabpils, Aknīste, Viesīte, Ilūkste and Subate which historically and geographically have never belonged to Latgale, while clearly Latgalian Varakḷāni is not mentioned in this strategy. The author believes that, with certain reservations, not only Ilūkste and Subate - as existing components of the Latgale planning region, can be counted in Latgale but culturally and historically - also Krustpils (the part of the city of Jēkabpils situated on the right bank of the Daugava river).

Thus, today there are 15 cities and towns in the Latgale region (see Table 1), which are significantly different according to their geographical location and natural environment conditions, area and spatial structure, demo-geographical and socio-economic indicators, as well as the administrative status.

Cities and towns in Latgale are forming several functional urban networks exceeding boundaries of the region. Support frame of the central urban network is constituted by the urban triangle - Daugavpils, Rēzekne and Jēkabpils, which is a major focal point in the direction from Latgale to the capital. These cities are directly linked to the major transport corridors and are building up polycentric structure of the Latgale region and in the future will provide the widest choice of various functions and high quality services [11].

\section{Territorial Development Index (TDI)}

TDI is a generalized indicator that shows the area development above or below the average national level of socio-economic development during the current year. For all the towns and cities in Latgale this index is consistently negative purporting that urban development in the region is below the national average. There are considerable variations in the index and the rank of the towns and cities can experience both a fall and a rise year by year.

According to the most recent data [12] it is evident that uppermost in ranking of the Latvian cities is Daugavpils (rank 22), Balvi (35) and Rēzekne (39), while Subate (70), Dagda (72), Viļaka (73), Varakḷāni (74), Viḷāni (75), Kārsava (76) and Zilupe (77) are traditionally at the bottom of the list of Latvian cities. It should be noted that positive trends in recent years have been witnessed in development of Daugavpils, Balvi, Krāslava, Ludza, Preiļi and Ilūkste [12, $13]$.

\section{Impact of administrative-territorial reform}

Administrative-territorial reform (2009) implemented in the Latvian state will inevitably affect the distribution of population, including urban structures of the Latgale region. All the towns and cities of the Latgale region have had realistic and geographically reasonable 
opportunities to become centres of the newly created regions, in which they have succeeded. Debatable is the question how the former district centres will develop further, since in the course of the reform process their status changed and the impact area became narrower, and whether small towns - centres of the newly created municipalities, currently has sufficient potential for development in order to fully perform the new functions.

Cities are interested in strengthening their impact areas and already existing social infrastructure base, as well as in attracting additional investments, which would promote creation of new businesses and facilitate more regular development of the state territory, reducing the existing regional disparities. Complex development programmes of municipalities are currently being elaborated to achieve this goal.

In assessing the potential of newly formed municipalities, first of all number of population and territory, it is possible to classify cities and towns of Latgale as follows:

- Daugavpils and Rēzekne - keeping their status of republican subordination cities, are strengthened also as centres of the largest municipalities in the region;

- Balvi, Ludza, Preilị, Krāslava - former district centres, - to a greater or lesser extent narrowing down their impact area, reducing their development potential;

- Dagda, Ilūkste, Līvāni - the biggest winners of the administrative-territorial reform, since by raising their status and significantly expanding the impact area, these are developing as centres of strong and viable municipalities;

- Kārsava, Viḷāni, Varakḷāni, Viḷaka, Zilupe - becoming centres of relatively small municipalities, failing to significantly increase their development potential and continue to languish;

- Subate - without becoming even a centre of small municipality, limits its development potential and is under threat of losing a town status.

\section{Depopulation threat}

Demographic situation in the Latgale region during the post-Soviet period vividly describes decline in population numbers or depopulation, as well as population ageing caused both by the negative population migration balance and the negative natural growth rate. If in Latvia the number of population has decreased by $5.6 \%$ since the beginning of the 21 st century, then in Latgale it has shrunk by as much as $11.9 \%$ [14]. Almost all the Latgale demographic indices are less favourable than in other regions of our country, for example, the natural growth is $-8.0 \%$ (average Latvian figure is $-3.7 \%$ ), while infant mortality is twice as high as in Riga. Proportion of the retirement age population even in big cities of the Latgale region is approximately half as much again exceeds the number of children under the age of 14 . Emigration is one of the factors that have significant impact on number of population in Latgale, which has particularly intensified since opening of the labour market in the old EU member states, putting socio-demographic and economic development of the region under threat. A very significant number of population has left cities and towns of the Latgale region within the last 5 years searching for employment, however, calculations of the emigration volumes are performed implicitly, hence they cannot be accurate - hopefully, the results of the 2011 Census will show the real situation.

Urban population dynamics in Latgale during the post-Soviet period is presented in Table 1, being set up on the basis of the information provided by annual reports of the Central Statistical Bureau.

Population has consistently decreased in all the cities and towns of the region, but differences have been observed in the dynamics of this process. At the beginning of the 21 st century depopulation intensified in most cities and towns of Latgale, including both regional cities and all the former district centres, while depopulation rate slowed down considerably in Līvāni, Dagda, Ilūkste and Zilupe. 
Resident population dynamics of the Latgale cities and towns in the post - Soviet period (1990-2010)

(calculated according to [15])

\begin{tabular}{|c|c|c|c|c|c|}
\hline City, town & 1990 & 2000 & 2010 & $\begin{array}{c}\text { Depopulation } \\
(2000 \text { to } \\
1990, \%)\end{array}$ & $\begin{array}{c}\text { Depopulation } \\
\text { (2010 to } \\
2000, \%)\end{array}$ \\
\hline Daugavpils & 126575 & 115574 & 103922 & 91,3 & 89,9 \\
\hline Rēzekne & 42832 & 39430 & 35074 & 92,1 & 89,0 \\
\hline Ludza & 11853 & 10857 & 9616 & 91,8 & 88,6 \\
\hline Krāslava & 12434 & 11414 & 10194 & 91,8 & 89,3 \\
\hline Līvāni & 12263 & 10379 & 9016 & 84,6 & 86,9 \\
\hline Balvi & 9340 & 8693 & 7903 & 93,1 & 90,9 \\
\hline Preili & 9421 & 8902 & 7988 & 94,5 & 89,7 \\
\hline Vil̦āni & 4608 & 4058 & 3483 & 88,1 & 85,8 \\
\hline Varaklāni & 2798 & 2421 & 2103 & 86,5 & 86,9 \\
\hline Kārsava & 3110 & 2726 & 2424 & 87,7 & 88,9 \\
\hline Zilupe & 2441 & 1951 & 1774 & 79,9 & 90,9 \\
\hline Viliaka & 2152 & 1848 & 1536 & 85,9 & 83,1 \\
\hline Dagda & 3325 & 2814 & 2512 & 84,6 & 89,3 \\
\hline Ilūkste & 3275 & 2969 & 2829 & 90,7 & 95,3 \\
\hline Subate & 1041 & 952 & 752 & 91,5 & 79,0 \\
\hline
\end{tabular}

Particularly worrying trend is observed in small towns of the Latgale region, within 20 years of independence having lost a quarter of the population on average, with the result that in Subate, Viliaka and Zilupe number of population is already inadequate for maintenance of the town status, since, according to existing legislation in Latvia, "the town status may be granted to settlements, which are cultural and business centres with developed engineering infrastructure and street network and which have not less than 2000 permanent residents "[16]. Indeed, the law also provides for exceptions.

\section{Environmental indicators}

A large number of pollution sources are concentrated in towns and cities; therefore the urban environment is characterized by high atmospheric pollution related to high intensity of traffic, industrial production and production of thermal energy. In accordance with existing procedures, the emission data from stationary pollution sources are defined according to methodological rules approved by the Ministry of Environment and Regional Development, while for assessment of urban transport pollution the data is required on the traffic flow intensity and dynamics, or variability in the space of weeks, days and hours [17].

The summarized information on air pollution caused by stationary sources demonstrates (see Table 2) that at the beginning of the 21st century in most cities of the Latgale region, in particular, Daugavpils and Rēzekne, air pollution significantly reduced. This is attributable to decline of industrial production (proportion of factories in emissions from stationary sources in Rēzekne accounts for only $13 \%$ and in Daugavpils - 42\%), as well as replacement of oil and coal with environmentally more friendly natural gas and local resources of wood, woodchips and peat used for the urban heating supplies.

The $\mathrm{SO}_{2}$ pollution being particularly hazardous to environment and health in most cities of Latgale now accounts for only a few percent and only in big cities of the region it varies within range of $10-20 \%$, moreover, amount of sulphur-containing emissions in Daugavpils is approximately 5 times higher than in Rezekne. 
Table 2.

Emissions from stationary air pollution sources in cities of Latgale region (tons) $[18,19]$

\begin{tabular}{|l|c|c|c|c|}
\hline \multicolumn{1}{|c|}{ City } & $\mathbf{1 9 9 8}$ & $\mathbf{2 0 0 3}$ & $\mathbf{2 0 0 5}$ & $\mathbf{2 0 0 9}$ \\
\hline Daugavpils & 8044 & 1340 & 911 & 719 \\
\hline Rēzekne & 2669 & 1368 & 1317 & 219 \\
\hline Krāslava & $\ldots$ & 576 & 472 & 359 \\
\hline Ludza & $\ldots$ & 215 & 226 & 210 \\
\hline Preili & $\ldots$ & 355 & 137 & 129 \\
\hline Balvi & $\ldots$ & 315 & 38 & 100 \\
\hline
\end{tabular}

If volumes of emissions from stationary sources in the atmosphere in cities and towns of the Latgale region are gradually decreasing, as much as persistent is the increase in environmental pollution caused by vehicle-produced exhaust gases and a variety of harmful by-products from operation of machinery. It is thought that road transport generates more than half of air pollution in urban areas and the highest atmospheric pollution is usually observed in the centre of a city and in industrial areas [20]. Impact of transport on the urban environment quality is displayed by the dynamics of amount of cars (see Table 3), the technical condition of vehicles and the traffic flow intensity on streets of cities.

Table 3.

Number of vehicles registered by the Road Traffic Safety Directorate in largest cities of the Latgale region [21]

\begin{tabular}{|l|c|c|c|c|c|c|}
\hline \multirow{2}{*}{ Area } & \multicolumn{3}{|c|}{1998} & \multicolumn{3}{c|}{2011} \\
\cline { 2 - 7 } & Trucks & Busses & Cars & Trucks & Busses & Cars \\
\hline Daugavpils & 2841 & 469 & 17790 & 2421 & 233 & 22401 \\
\hline Rēzekne & 1613 & 363 & 7154 & 1211 & 152 & 9148 \\
\hline
\end{tabular}

Level of automobilization in urban Latgale is significantly lower than in the country as a whole, for example, number of the registered cars per 1000 inhabitants in Rezekne in 2011 constituted 261, Daugavpils - 217, but in Latvia on average - 415 units. At the beginning of the 21st century the number of cars in urban areas of the Latgale region increased approximately by a quarter, while the number of trucks and busses decreased by approximately the same amount. We can unequivocally declare that the maintenance condition of vehicles has significantly improved within the last 5 years, and hence the decline in the pollution of the environment caused by them, however concerns are due to considerable consumption in Latgale of the semi-legal fuel imported from Russia and being less environmentally friendly.

Annual traffic intensity measurements carried out by students of the Rezekne Higher Education Institution at intersections of the main city streets suggest that the intensity of the vehicle movements in Rezekne during the period 2000 - 2007 increased by $35 \%$, but the growth has come to an end recently. More than 1,000 vehicles, mainly cars and vans, cross the busiest city streets intersections within one hour on weekdays, while the most environmentally friendly mean of conveyance - bicycle, in the streets of Rezekne is making only about $1 \%$ of the enumerated amounts of vehicles. It is observed that the frequency of bicycle use is significantly higher in small towns of the Latgale region. Air quality lichenoindication research does not present particularly high atmospheric pollution in cities and towns of the Latgale region, however significantly worse air quality is found in urban areas adjacent to railways. 
Within framework of the study "Trends of the Latvian Urban Socio-economic Development" in seven cities of Latgale region in 2007 - 2008 the survey was carried out to ascertain public opinion with regard to satisfaction with the city where they live. The survey results show that the population of Balvi, Preiļi and Krāslava has most appreciated their place of residence (more than 2/3 affirmative responses). In Ludza, Rēzekne and Līvāni the number of residents being satisfied with their place of residence was just over $50 \%$. However in Daugavpils, despite the lowest unemployment rate in the region, only $40.5 \%$ of respondents were satisfied with their city, and even then only $\sim 20 \%$ were satisfied with the ecological situation at their place of residence. In other towns of Latgale the population has also evaluated the environment quality more critically than the overall standard of living [22].

\section{Projects for Development of Urban Environment}

After Latvia acceded to the EU (2004) in towns and cities of the Latgale region had been commenced implementation of important and financially large-scale projects for improvement of urban environment, in which an average $85 \%$ of the project costs are covered by the EU ERDF and the Cohesion Fund. This has contributed to increased volumes of construction, urban landscape transformation, as well as increased intensity of land use. In cities large-scale reconstruction operations of the main streets are taking place, traffic overpasses and bridges are being built or reconstructed, municipal heating system is brought into order. For example, in Daugavpils only for implementation of the street infrastructure development projects in 2010 funds amounting to LVL 38.3 million were allocated [23].

In cities and towns of the Latgale region construction of major tourist, cultural and sports facilities has been initiated or completed. In Daugavpils have been discussed such ambitious projects as the complex development of the fortress and foundation of the M. Rothko Art Centre, as well as the idea of the international airport on the former Lociki military aerodrome site. While Rēzekne since the end of 2009 has turned into a huge construction site, as at the same time in the city was initiated construction of the creative service centre for Eastern Latvia and of the Eastern Latvia regional multi-functional centre (Concert Hall), as well as a pedestrian street joining these objects and reconstruction of Atbrīvošanas alley. It should be noted that efficiency of implementation of these projects for various reasons has not received straightforwardly positive evaluation among the urban population.

Practically in all the cities and towns of the Latgale region complex water management development projects are implemented, which include renovation and expansion of the water and sewerage systems, as well as construction of drinking water and iron removal plants and new sewage treatment plants. For example, in Krāslava centralized water supply is now available for $97 \%$ of the urban population (previously $-81 \%$ ), and centralized wastewater collection is provided for $81 \%$ of the population (previously $-59 \%$ ), while the overall cost of the project was LVL 12.3 million [24]. We can affirm that the quality of drinking water in towns and cities of the region now complies with all the EU regulations.

Important measures have been taken for improving the municipal waste management systems: near Daugavpils and Rezekne up-to-date regional municipal waste management landfills have been built, separate waste collection has been introduced in the cities. For improvement of the tourism infrastructure several cross-border cooperation projects are being implemented in cooperation with Lithuanian, Belarusian, Russian and Estonian local governments. At the beginning of the 21 st century in Latgale scientific research potential significantly increased, by means of the regional universities, involved in major international research projects and modernization of material and technical facilities for research work. 


\section{Conclusion}

1. The beginning of the 21st century has marked a new milestone in urban development of the Latgale region, conditioned, to a decisive extent, by Latvia's accession to the European Union (2004), which has contributed to attraction of substantial international investments for implementation of various development projects of urban environment.

2. Urban environmental quality in the Latgale region has significantly improved, which is mainly associated with transition to environmentally friendly fuels and implementation of many, environmental projects, basically the EU-funded, as well as with a decline in industrial production.

3. After several years of dynamic development, the economic crisis, which began at the end of 2008, has affected Latgale harder than other regions of the country, to which has contributed slow pace of industrial restructuring, insufficient funding, considerable distance from the national capital Riga and unsettled inter-state relations with Russia and Belarus.

4. The regional cities Daugavpils and Rēzekne are characterized by more dynamic development pace and less explicit depopulation, while in the small towns of the region positive development processes have been considerably more difficult, and they have already lost about a quarter of the population.

5. Serious concerns are created by the steady decline in the number of population in all the Latgale region's towns and cities, the rapid ageing of the society, persistently high unemployment rate, social exclusion and apathy dominant in the region, as well as deepening of regional inequalities.

6. In order to prevent threats to the sustainable development of Latgale, strengthening of urban functions in the entire region is required, which would allow to increase the viability of the peripheral territories and to smooth out regional disparities. This is particularly important since exactly the direct implementation of the principles of cohesion has been declared as one of the cornerstones of the EU regional policy.

\section{Acknowledgements}

The research and the article were supported by European Social Fund (ESF) project Nr.2009/0227/1DP/1.1.1.2.0/09/APIA/VIAA/071 "Linguo-Cultural and Socio-Economic Aspects of Territorial Identity in the Development of the Region of Latgale"

\section{References}

1. Matisovs, I. Quality of the Urban Environment Landscape and its Influencing Factors in Latgale.//V International scientific and practical conference „Environment. Technology. Resources.” Collected articles.- Rēzekne: Rezekne Higher Education Institution, 2005 /in Latvian: Matisovs, I. Pilsētvides ainavas kvalitāte un to ietekmējošie faktori Latgalē.//V Starptautiskās zinātniski praktiskās konference „Vide. Tehnologija. Resursi." Rakstu kräjums.- Rēzekne: RA, 2005/.

2. VASAB 2010+. Spatial Development Action Programme: Vision and Strategies around the Baltic Sea 2010. Wismar, 2001.

3. The Territorial Agenda of the European Union. http://www.eu-territorial-agenda.eu/ (viewed 25.02.2011)

4. Latvian National Development Plan /in Latvian: Latvijas Nacionālais attīstības plāns/ 2007-2013. http://www.nap.lv/in site/tools/download.php. (viewed 26.02.2011)

5. Priority "Polycentric development" /in Latvian: Prioritāte „Policentriska attīstība"/ http://www.raplm.gov.lv/pub/index.php?id=2469 (viewed 27.02.2011)

6. http://www.daugavpils.lv/upload/2010_dok/departamenti_un_nodalas/attistibas_departaments/ievads_un_si tuacijas_analize2010.pdf (viewed 28.02.2011.)

7. http://www.rezekne.lv/uploads/media/I_Esosas_situacijas_raksturojums_14_01.pdf (viewed 28.02.2011)

8. Vanags, E., Vilka, I. Activities and Development of Local Governments. /in Latvian: Pašvaldību darbība un attīstība/. Rīga: LU Akadēmiskais apgāds, 2005.

9. Survive though changes, Latvia diverse. Riga, Central Statistical Bureau of Latvia, 2008 /in Latvian: Mainoties saglabājies, dažādā Latvija.Rīga, LR Centrālā statistikas pārvalde, 2008/.

10. Latgale urban development strategy /in Latvian: Latgales pilsētu attīstības stratēgijal (2001). http://www.latgale.lv/lv/files/download3 (viewed 20.12.2010) 
11. Valdmane, I. Spatial plan of the Latgale region /in Latvian: Latgales regiona teritorijas plānojums/. Latvijas architektūra. \#3 (65)/2006.112.-116.

12. Regional development in Latvia 2009. Riga: State Regional Development Agency, 2010. /in Latvian: Reǵionu attīstība Latvijā 2009. Rīga: Valsts reǵionālās attīstības aǵentūra, $2010 /$. http://www.vraa.gov.lv/uploads/Regionu_attistiba_Latvija_2009.pdf (viewed 20.02.2011)

13. Diversity of Latvia in numbers and visions. Rīga, Central Statistical Bureau of Latvia, 2009 /in Latvian: Latvijas dažādība skaiţ̦os un vīzijās. Rīga, LR Centrālā statistikas pārvalde, $2009 /$.

14. Depopulation in Latvia. Managing editor Zvidriņš, P. Riga: LU Academic Publishing House, 2010 /in Latvian: Depopulācija Latvijā. Atb. red. Zvidriňš, P. Rīga: LU Akadēmiskais apgāds, $2010 /$.

15. Demography 2010. Statistical data collection. Riga: Central Statistical Bureau of Latvia, 2010 /in Latvian: Demogrāfija 2010. Statistisko datu krājums. Rīga: LR Centrālā statistikas pārvalde, 2010/.

16. Law On Administrative Territories and Populated Areas (2008). http://www.likumi.lv/doc.php?id=185993 $\&$ from $=$ off (viewed 25.12.2010)

17. Environmental Impact Assessment. Riga: Environmental Impact Assessment State Bureau, 2002 /in Latvian: Ietekmes uz vidi novērtējums. Rīga: Ietekmes uz vidi novērtējuma Valsts birojs, 2002/.

18. Environmental indicators in Latvia. Collection of statistical data. 2004-2010. Riga: Central Statistical Bureau of Latvia, 2004-2010.

19. Regions of Latvia in numbers 2001.- Riga: Central Statistical Bureau of Latvia, 2001 /in Latvian: Latvijas reǵioni skaiţ̦os 2001.- Rīga: LR Centrālā statistikas pārvalde, 2001/.

20. Environmental Science. Ed. Kl̦avin̦š, M. Riga: LU Academic Publishing House, 2008. p. /in Latvian: Vides zinātne. Red. Kļaviņš, M. Rīga: LU Akadēmiskais apgāds, 2008.

21. Distribution of Vehicles in Towns and Municipalities /in Latvian: Transporta līdzekļu sadalījums pilsētās un novados/. http://www.csdd.lv/?pageID=1296470925. (viewed 01.02.2011)

22. http://www.raplm.gov.lv/uploads/filedir/Nozares/Petijums_Lv_pils_soc_ek_att_tend.pdf (viewed 04.03. 2011.)

23. Minova, I. Attīstības departaments piesaistīs pilsētai papildus 25 miljonus latu /in Latvian: Departament of Development will attract extra 25 million lati for the city/. Latgales Laiks, 18.02.2011.

24. Krāslava city is not contaminating the Daugava any more /in Latvian: Krāslavas pilsēta vairs nepiesārņo Daugavu/ Neatkarīgā Rìta Avīze, 03.03.2011. 